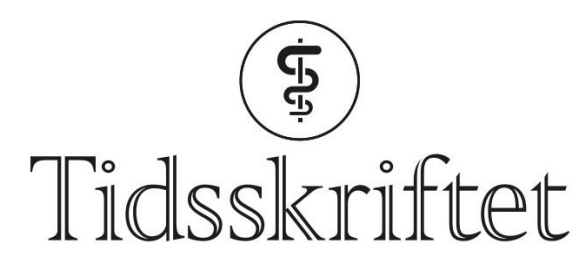

DEN NORSKE LEGEFORENING

\title{
«Skutt blir enhver»
}

TIDLIGERE I TIDSSKRIFTET

SYNNE LOFSTAD

E-post: synne.lofstad@hotmail.com

Redaksjonssjef i Æsculap

Etter marsutgaven i 1940 blir det brått en pause i Æsculaps utgivelser. Da magasinet endelig er tilbake i juni, er forsiden til minne om fem medisinstudenter som falt under invasjonen. Redaktøren ser i sin leder på tingenes tilstand med både humor og alvor (Æsculap 1940; 21: 69-71).

\section{Æsculap.}

Når vi nå kommer igjen etter en sørgelig pause, vil vi for det første gjøre våre lesere oppmerksom på at vi fremdeles lever, og det akter vi å fortsette med inntil videre. Æsculap er 21 år, og midt i sin skjønneste ungdoms vår, og vil ikke legge seg på likstrå før alvorlig inanisjon med hensyn til papir og trykksverte fremkaller mors. Det er mulig at vi blir litt slankere, innskrenkninger blir jo nødvendige på så mange områder. Men vi kommer igjen! 


\section{OPROP!}

Jeg har fått overdratt opgaven å sikre Norges land mot angrep fra Vestmaktenes side. Den norske regjering har avslatt flere tilbud om samarbeide. Det norske folk må nu selv bestemme over sitt fedrelands skjebne.

Blir opropet efterkommet, som det med stor forståelse blev gjort av det danske folk som befant sig i samme situasjon, vil Norges land bli spart for krigens redsler.

Blir det ydet motstand, og tilbakevises hånden, som rekkes frem i vennskapelig hensikt, ser jeg mig tvunget til å gå frem med de skarpeste og hensynsløseste midler for à bryte motstanden.

For krigsretten kommer den som understotter den av den flyktede forhenværende regjering utstedte mobiliseringsordre eller utsprer falske rykter!

Skutt blir enhver sivil person som blir påtruffet med våpen $\mathrm{i}$ hånd!

Skutt blir den som ødelegger anlegg som tjener trafikken og efterretningsvesenet eller kommunale innretninger!

Skutt blir den som anvender krigsmidler som står i strid med folkeretten (dum-dum).

Den i mange kamper seirrike tyske hær, det store og mektige flyvevåpen og krigsmarinen innestår for at dette mitt oprop vil bli gjennemfort.

\section{Den tyske øverstkommanderende von FALKENHORST \\ General der Infanterie.}

Figur 1 Oppropet fra Den tyske øverstkommanderende von Falkenhorst, General der Infanterie.

Faksimile: Eidsvoll museum, Akershusbasen / Museene i Akershus

Vi har av og til presset trykkefriheten temmelig langt

Vi må imidlertid innrette oss på å ta de hensyn som situasjonen krever. Æsculap har alltid hatt litt av et frispråk, - vi har av og til presset trykkefriheten temmelig langt. Det er slutt med det nå. Skal Æsculap fortsette med å leve inntil videre, må det tre fram på faglig basis, fram for alt uten enhver politisk tendens. Vi har den store tro om oss selv at vi skal klare det så noenlunde. Overfor plakatenes «Skutt blir enhver» kan en klare det utrolige. 


\section{ESCULAP.}

\section{ORGAM FOR MEDICINERE.}

Juni 1940

\begin{tabular}{c|c|c}
\hline Nr. 4V & $\begin{array}{c}\text { Utkommer med oo nr. om áret og koster kr. 2.50 fritt tilsendt. } \\
\text { Lossalg } 35 \text { ore, } \\
\text { Ekspedisjon: Universitetsgaten 24, Olaf Norli. }\end{array}$ & 21. Årg. \\
\hline
\end{tabular}

nnhold: Til legene. - Esculap. • Hodepine, av reservelege Refsum. • Fra sarutvalget. • Ukens lyspunkt.

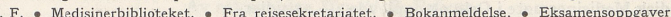

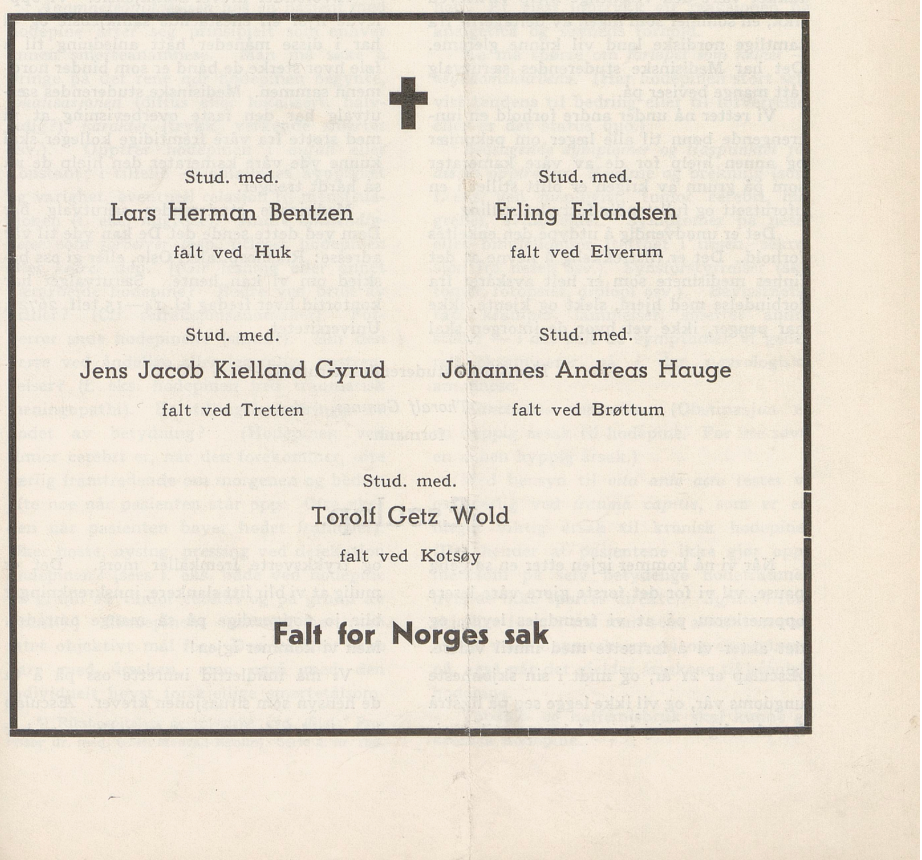

Figur 2 Faksimile av Asculap nr. 4 fra 1940.

Overfor plakatenes ‘Skutt blir enhver' kan en klare det utrolige

Våre lesere vil forstå at Æsculap har vanskeligheter å kjempe med nå, ikke minst på det $\emptyset$ konomiske område. Annonseinntektene uteblir delvis. Vi vil derfor be våre lesere om å støtte oss i størst mulig utstrekning ved å betale den vesle abonnementsprisen regelmessig, ved å skaffe oss nye abonnenter, og ved å skrive i Æsculap så det kan bli et godt og aktuelt medisinerblad også under de nåværende forhold.

Red.

Publisert: 16. mars 2020. Tidsskr Nor Legeforen. DOI:10.4045/tidsskr.20.0081

(C) Tidsskrift for Den norske legeforening 2020. Lastet ned fra tidsskriftet.no 